\title{
Recalling Community \\ Using material culture and digital archives in Salford
}

\section{Lawrence Cassidy}

Gateways: International Journal of Community Research and Engagement Vol 5 (2012): 166-82 (C) UTSePress and the author

ISSN 1836-3393
This article explores strategies for engaging geographically fragmented urban communities as active participants in conceptually re-mapping their former localities. It looks in detail at the ongoing Retracing Salford project in Salford, UK, which employs the use of everyday objects and oral histories, to engage and enable former residents to reconnect with their recently demolished neighbourhoods, as well as to each other, and document an urban working class history largely overlooked by the large-scale institutions.

The project is based on a PhD study undertaken by the author at The District Six Museum in Cape Town, South Africa, which examined the use of material artefacts in exhibitions and memory workshops at that museum, and explored how such strategies could be implemented in Salford, UK (Cassidy 2009). Like District Six, Salford has undergone wide-scale demolition and population dispersal over the past 40 years.

Over four years, from 2005 to 2009 , objects relating to the demolished urban districts of Salford were collected. These included street signs, family photographs, street maps and home movies, and formed the basis of the Retracing Salford project. Since 2009, they have been exhibited in spaces such as museums, community centres and libraries etc. The installations aimed to rejuvenate a sense of place, despite the eradication of the built and social environment. Wide-ranging responses were then collected from former residents as oral histories and used in the installations. Written records also contributed to a more in-depth overview of life in the district. The project has since developed, by using digitised versions of the family snaps, street signs and oral histories and uploading them on an ongoing basis to the internet, as a developing online Streets Museum archive (www.streetsmuseum. co.uk). Different sections of this digital archive show key elements of life in the districts of Salford. The site also contains pages on streets, sport, schools, workers, pubs, places etc. In the past two years this work has been developed by a small team of community arts workers, including an oral historian, a web designer and other community artists, who are engaging diverse age groups in the 
process. What began as a project focussed solely on the Salford 7 district has expanded to also include districts 3,5 and 6 . We have had a significant response to the project from hundreds of former residents who have kept objects in their homes, sometimes for decades, and donated them to us. Salford residents have overwhelmingly demonstrated to us that they want a space of interactive urban commemoration, where educational outreach is a central part of the legacy of the districts that were destroyed.

This article first provides an overview of the land clearances in Salford, which are still ongoing. It then presents a detailed discussion of the Retracing Salford project and reflects on how the methodology employed has helped rejuvenate and reconnect these dispersed communities. The article argues that the simple, low-cost employment of everyday artefacts, exhibited in accessible locations, is succeeding in widening the circle of participation and debate in relation to heritage issues, in particular the absence of commemoration of working-class community culture in the city. This approach has also increased awareness of urban land clearance issues. However, the project is constantly evolving and its continued success depends on numerous factors, such as developing new and existing strategies of engagement with the community, regularly gaining publicity and organising new exhibitions and workshops. Potentially, the collection of material artefacts could be utilised as an interactive online resource, for residents to access, share memories and maintain links. As well, it is hoped that one day the physical collection will become a permanent installation, either in an independent site, or within an existing museum.

\section{SALFORD 7: HISTORICAL CONTEXT}

The border of Salford 7, the initial focus of the project, begins less than a mile from Manchester city centre. The area was a high-density factory suburb, housing networks of families that formed over generations. The population expanded rapidly during the 1870s and 1880s, as multiple rows of terrace streets were constructed to house workers. Many of the houses were owned by landlords, and later companies, who rented the properties out to the families of the district. Larger, wealthier houses in the area lined the streets into Manchester city centre and occupied other prime locations, close to parks or squares, or were situated on the periphery of the district. The district was predominantly white working class, however, parts of it also contained a culturally and racially diverse population. There was a substantial Jewish population, many of whom were forced from Russia and Eastern Europe during the late 19th century and also after the Second World War. Later, in the 1960s and 1970s, other immigrant groups arrived, including Irish, Greek, Italian, Ukrainian, Yugoslavian, Polish and other Eastern European nationalities. The area had a particularly strong community spirit and rich street life, as successive generations grew up in the terrace streets and extended family networks knitted the community together. Throughout the 
Figure 1: Lower Broughton, Salford 7, 1930

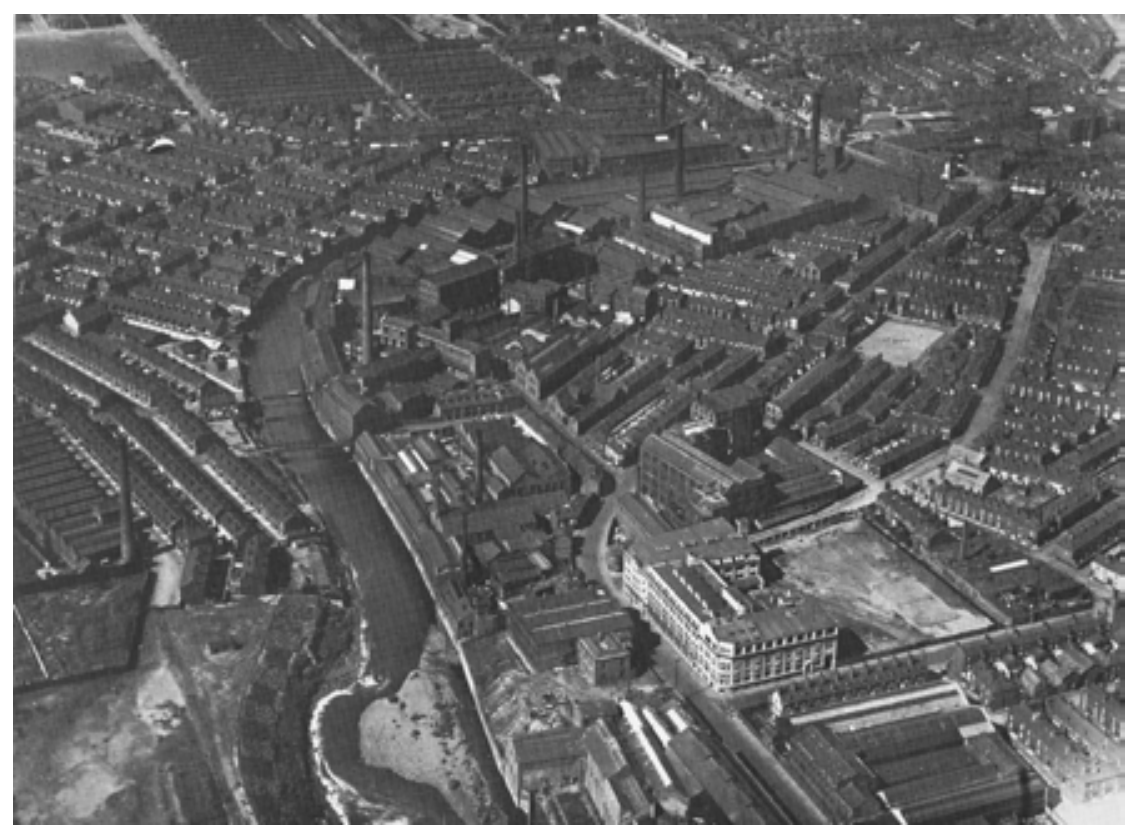

19th century, the social and architectural composition of the area remained largely unchanged (Figure 1).

\section{Slum Clearances}

The process of 'slum' clearances in Salford began in the 1950s and 1960s with the oldest, most centralised sections of the city and extended outwards. In the mid to late 1970s and early 1980s, the Lower Broughton area of Salford 7 underwent mass demolition. During this time its population almost halved, as the local authority used compulsory purchase laws to clear and reclaim whole sections of the city. (For example, in 1931, Lower Broughton had a population of almost 18500 ; today, its population is approximately 2500. (Salford City Council, 2007). Other areas in the city were also completely erased during those decades. During the 1970s, some residents' groups in the Lower Broughton area attempted to oppose the clearances, with the help of Salford University students, and a minority of streets survived because of their efforts. However, in the absence of meaningful participation in the decision-making process, virtually all terrace streets, local shops and related buildings were cleared at this time (Shapely 2007). Decisions were continually made using a top-down strategy, with planning consultants drafted in to Salford to decide on future development. When the heavy industries declined and the older terrace houses were cleared, many of these patches of land were subsequently occupied by large-scale light engineering factory units, or consumer goods warehouses, with sophisticated security or surveillance systems. These sites have continually expanded in number and scale. Today a large newly built casino and a series of expensive car showrooms line the road into Manchester city centre (Cassidy 2009).

The image and myth of the 'slum' and the 'slum dweller' has long been associated with Salford (Roberts 1971), and is historically rooted in mid-nineteenth century descriptions of elements of the working class in Manchester (Engels 1958). Certain districts were described as degenerate, not only physically, but also morally. 
This legacy of representation has spanned successive generations. During the Victorian period, for example, the working class, or sub-class, were described as a form of contagious disease, their mere presence in an area being sufficient to spread immorality (Kidd \& Roberts 1985).

Undoubtedly, poverty was a feature of the Salford 7 district. Many landlords and companies were solely concerned with generating profit and subdivided large properties, often not maintaining them. However, other properties were extremely well cared for, and their ornate features retained. The architectural quality of many streets also differed widely and many of the streets were in good order. Some houses were Victorian and Georgian mansions and could potentially have achieved listed status. A whole mix of architectural styles and periods existed. Yet, over 120 years after Engels and other Victorian reformers made their initial observations, the images of the urban 'slum' and the 'slum landlord' still lives on in collective memory, and it was this argument that was used to justify the demolition of whole enclaves of the city. However, the 'slum' conditions that existed in Salford 7 in the 1970s were significantly enhanced, if not created, by this very demolition and by leaving properties boarded up and run down for years on end prior to demolition. Once the line was drawn and residents knew demolition was unavoidable, then, logically, people lost the will to look after the properties.

After the demolition of the terrace streets in the 1970s, the remaining residents of the area were relocated to peripheral housing estates on the edge of the city, or to high-rise flats. A minority of the original population were re-housed in the immediate area. This was achieved by rapidly constructing new council houses at a much lower density. The local council was under pressure, as Manchester was expanding outwards and had made potential plans to design new road networks to plough through the district. At first, these houses were well maintained and the community took pride in living in them. Some families continued to live close to each other, as small clusters of original networks, and there was still some form of social infrastructure, including local shops, older streets, pubs, care homes, clubs and schools. However, since the early 1980s, unemployment, social breakdown and antisocial behaviour have significantly increased, whilst local facilities have been steadily erased. In the past 15 years, the area has gained a negative reputation in the media for crime, unemployment and related social problems.

Despite this, the few original extended families that remain have generally stayed together and have contributed to maintaining the community throughout these years, when many others left.

\section{Current Regeneration and Demolition}

There is currently another wave of demolition sweeping through the area, affecting virtually all the houses built in the 1970s and the few remaining older terrace streets, further fragmenting the native population. This latest round of 'regeneration' is part of a 
Figure 2: The destruction of cultural heritage, Broughton, Salford 7, 2010

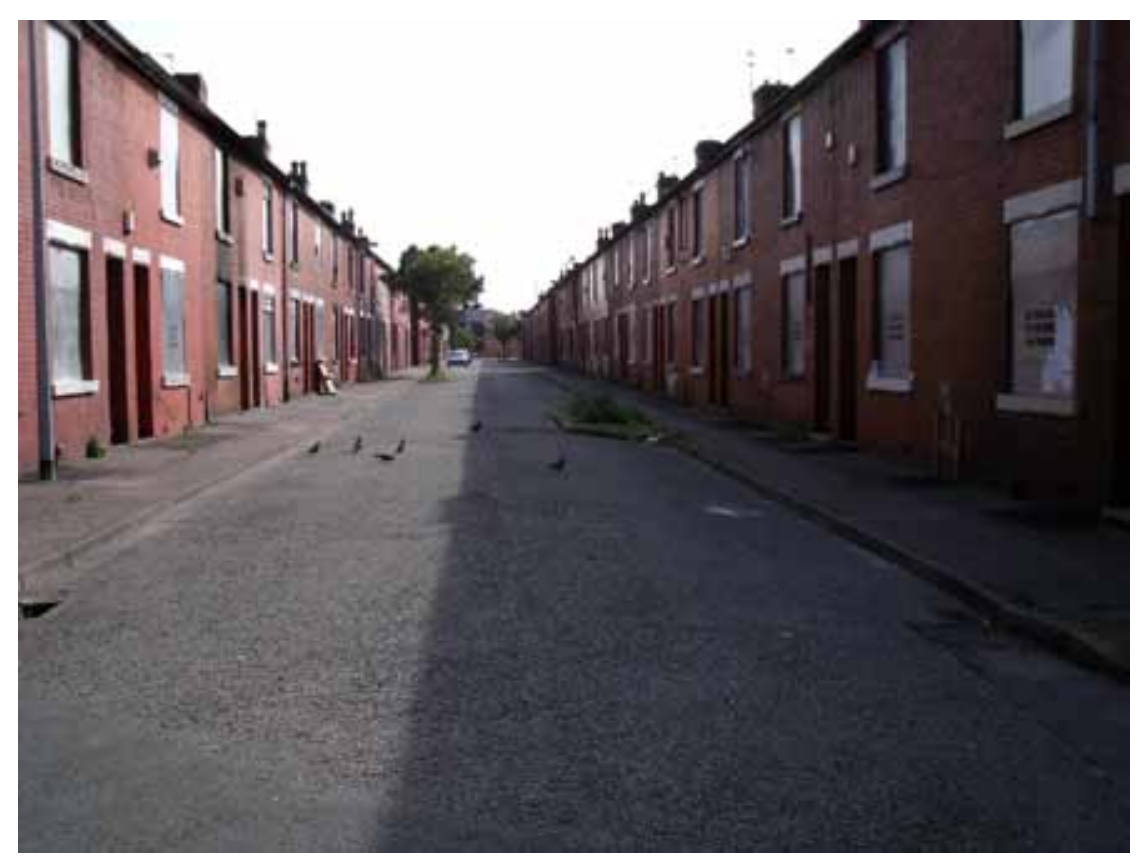

public-private partnership between the local council and property developers, and is driven by central Government's Housing Market Renewal Initiative, which targets urban inner-city areas highlighted as economically failing. Over the past five years, in numerous industrial areas in northern UK, local government and development companies have used a combination of strategies on an ongoing basis to redesign urban districts into neighbourhoods of 'choice', resulting in the mass demolition of Victorian terrace housing and the large-scale relocation of long-term working-class residents (Figure 2).

This has also been the case in the Salford 7 district. In the months and immediate years prior to the current construction of new houses, certain streets slipped into further decline, the environment became increasingly threatening, property prices collapsed, residents gradually left, and houses were demolished and their occupants relocated outside the area. Other residents left out of 'choice', or were offered housing outside the area. A percentage of the original inhabitants were re-housed and were superficially involved in some consultation. However, this was largely cosmetic, as restructuring and demolition plans had already been made before residents had been consulted (Somerville 2012). On the whole, a new community has steadily been implanted and the area has been rebranded. It now consists of apartments and houses.

Many of the publicly owned high-rise flats built in the 1950s, 1960s and 1970s have also been demolished, or privatised, and are now gated communities, or student mini-cities. This is also part of the ongoing regeneration of the city and the area. Consequently, in Salford, most older, established communities have gradually been relocated to peripheral estates, as Greater Manchester has come to symbolise the policy of overspill. It is estimated that over 1000 streets have been demolished in different districts in Salford over the past 70 years. Some sections are only just being built on, after lying empty for 35 years. There are currently hardly any 
Figure 3: The destruction of 1970s housing, Lower Broughton, Salford 7, with the Church of Ascension in the background, 2011

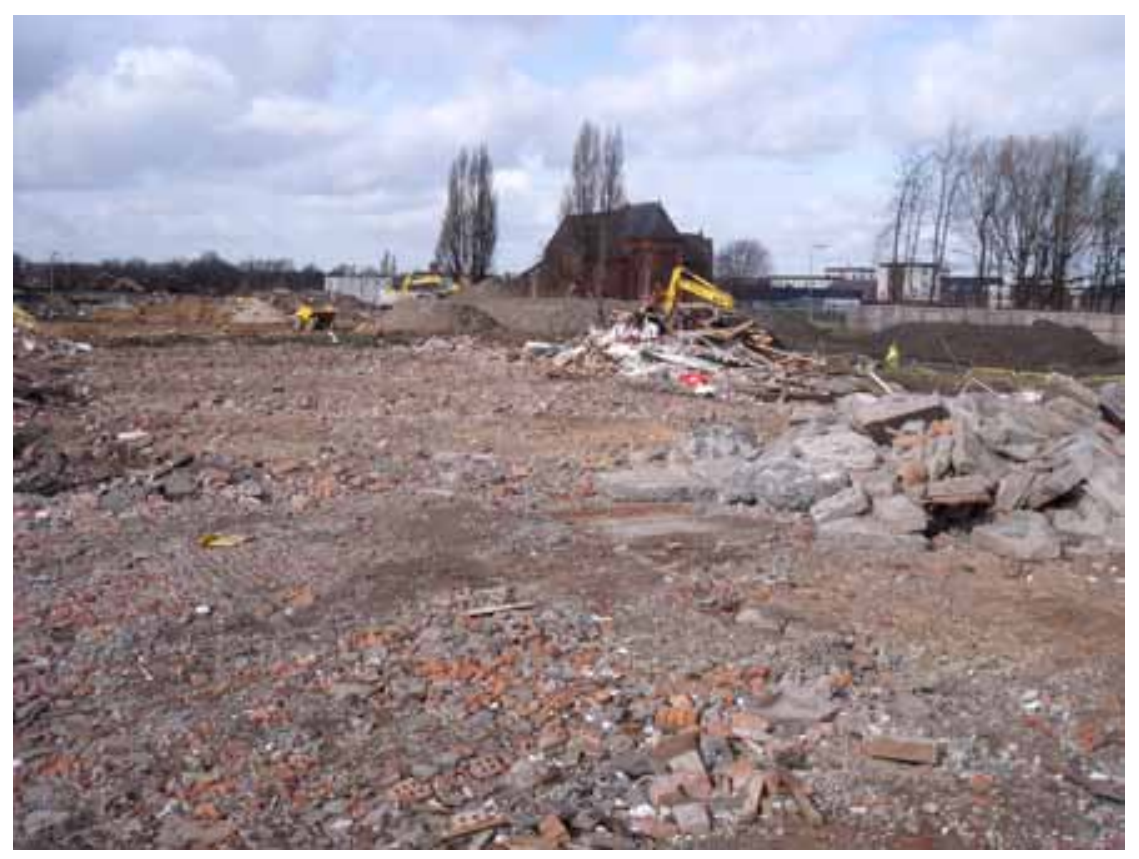

architectural features left untouched by demolition, apart from the odd building such as the heritage-listed Church of Ascension (Figure 3). This has resulted in the formation of a kind of ghost city, which most residents over the age of 40 or 50 can still remember living in.

The successive rounds of demolition in Salford have resulted in long-term social polarisation and health problems. Whilst some area clearances were necessary over the past 40 years, due to longterm landlord neglect and general deterioration, well-maintained streets and buildings were also destroyed. The ongoing demolition process has been subjected to substantial critical academic analysis from a number of different perspectives, including: as a destruction of architectural heritage and a cultural/human rights issue (Cassidy 2009; Wilkinson 2006) as a form of cultural domination and eradication (Allen 2008); as having a significant negative impact on health (Mallinson 2003) and wellbeing (Woolrytch \& Sixsmith 2008); and as a re-enactment of historical strategies of spatial segregation (Cassidy 2009, 2012a). Today, multiple indices of deprivation statistics reveal huge problems in the area (Cassidy 2009).

\section{THE VALUE OF PLACE: DISTRICT SIX, CAPE TOWN}

Despite ongoing demolition programs in urban areas, the value of place is increasingly being recognised by official bodies. English Heritage (2008) has recently identified a series of conservation principles relating to the sustainable management of the historic environment. This organisation states that certain values should be recognised in relation to conserving historic sites. These include communal value (Schofield 2009), which concerns the meanings of place for the people who relate to it or feature it in their collective experience or memory; commemorative and symbolic value, which reflects the meaning of place for those who draw part of their identity from it, or have emotional links to it (as part of a wider analysis of other international sites of conflict, John Schofield 
(2009) discusses the earth of the District Six area and The District Six Museum as an iconic example of this kind of value); and social value, again defined as places that people perceive as a source of identity, distinctiveness, social interaction and coherence. Some places are modest and everyday; others are reflective of regional and national identity.

As mentioned, much of the impetus for developing the Retracing Salford project came from seeing the work done by the District Six Museum in Cape Town, South Africa. During the 1970s, around 60000 people were forcibly removed from District Six in Cape Town by the apartheid regime, and their homes destroyed when it was declared as a 'White Only' area under The Group Areas Act. Successive generations of families had lived in the area, forming deep attachments to the place (Western 1996). Consequently, the destruction of it produced a profound psychological wound and the effects of this contributed to the formation of a community-based movement to reclaim the site. This movement, known as 'Hands off District Six', eventually evolved into the District Six Museum, which opened in 1994, as a land claims court. The material remnants collected from the district were used in memory workshops as legal evidence for relocating residents back to their former homes.

While there are historical differences between the underlying issues surrounding the destruction of District Six in Cape Town and the Salford 7 area - poverty rates in the UK are substantially less extreme than those in Cape Town, for example - there are also many common threads: both districts are located next to cities that represent past symbols of regional and international wealth and power; both areas were associated with 'slum' districts, and the mass housing clearances were undertaken in the name of social improvement; established family networks, formed over generations, were fractured and lost; local residents were relocated significant distances from their original district, often to the periphery of the city or beyond; and over 90 per cent of the architectural fabric in each district has been cleared in the past 40 years or so, completely modifying the urban grid. Some tracts of land in Salford 7 have remained uninhabited for over 35 years, as is also the case in District Six.

Today, in both cities, there is still a huge gap between affluent and deprived areas that has now spanned various generations (Cassidy 2009; Dorling 2007; Peck \& Ward 2002). The social and architectural landscapes of both cities can be read in related terms: as examples of power and domination, and as the selective commemoration of particular histories and the exclusion and ongoing destruction of others. Many communities in Manchester and Salford have now been erased and completely excluded from 'official' commemoration by museums. None of the working-class districts that were formed over generations in central Manchester, such as Angel Meadow, Chorlton-On-Medlock, Red Bank, Ancoats, Hulme, Little Italy, Little Ireland, or Collyhurst are represented in any museum as a permanent display. In Salford, 
the districts of Greengate, Ordsall, Broughton, Langworthy, Islington, Hanky Park, Whit Lane, Ellor Street and Bexley Square are not represented anywhere as permanent displays. There have been temporary exhibitions of urban communities, but they are never given permanent or prominent spatial institutional commemoration.

However, the example set by The District Six Museum shows that a community-centred process can be developed, maintained and valued in a far deeper way than what can be achieved by drafting in outside professionals. As well, long-term sustainable community links can be maintained through such a process. This has been demonstrated by the range of projects that continue to be popular at The District Six Museum, such as local and international youth projects, memory workshops with ex-residents, schools outreach and critical educational projects, as well as residents' clubs, learning programs, conferences, student placements, community-based radio and TV, digital archiving projects and a whole variety of related events. On the whole, the District Six museum, as a community-based movement, uses artefacts within a politics of critical reflection which raises particpants' consciousness and develops the tools of critical inquiry. It contributes to breaking the culture of silence of oppressed people. This form of experiential learning is largely absent in Salford and Manchester and is something we have encouraged in our workshops in Salford. Such an approach works towards demystifying the structures and processes of the society within which the museum works (Soudien 2008, p. 116), and gives everyone a role to play in the process, including intellectuals, educators, museum professionals and community groups.

\section{RECLAIMING SALFORD}

The community-inspired outreach program Retracing Salford has been operating for the past 3 years. Inspired by the first major exhibition at The District Six Museum in Cape Town - Streets, Re-Tracing District Six - it aims to collect material from demolished urban areas of Salford, such as maps, home movies, oral histories and street signs, as well as family snaps, and exhibit them in local venues. In this way, material culture is used to recall and rejuvenate wide-ranging memories of the near past, facilitating the collection of information on past street conditions, street life and the processes that were used to expedite demolition. Related images and histories are also collected from now demolished high rise flats. Ex-residents who visit the exhibitions are invited to donate material and are also interviewed and the accounts of their experiences recorded. The collected material, including some of the oral histories, is then placed on an online digital archive, which can be seen at www.streetsmuseum.co.uk. The Streets Museum archive is designed to fill the substantial gaps left by museums, whose role it is to explore city histories, yet are doing so only selectively (Bennett 1995; Kavanagh 1999; Macdonald 1998). 
Supporting the 'collection' of digitised artefacts is a physical outreach program of this online archive, which travels around the city, as a mobile museum. The installations were made with a team of people from community organisations and are designed to create active sites of memory that local visitors can easily access. Venues include traditional museum spaces as well as alternative locations like community centres, churches and clubs. These alternative spaces are important, as local residents tend not to visit museums, due to lack of transport and cultural capital. The exhibitions provide a space for communities to impose their own version on the recent past, as a form of emotional mapping, enabling them to reflect on personal and family memories (Bagnall 2003).

\section{USING MATERIAL CULTURE}

Alongside the family snaps, maps and street signs, we collect home movies mostly made during the 1960-70s. These movies can reveal evidence of the built environment that has now been destroyed and how locals interacted with it. The films focus on cultural traditions and religious processions that have now ended, as a way to perpetuate collective memory through group viewings (Connerton 1989). As the films were made by local people, they reveal a sense of place rooted in local knowledge, that contrasts with outside perceptions of the area as a slum district housing a demoralised population (Norris Nicholson 2000). They place the politics of representation back into community hands and challenge the negative stereotypes of working-class culture often found in current fine art photography (Samuel 1996).

The use of multiple family snaps in the installations was intended to achieve related aims. The snaps were made into posters or exhibited on three-dimensional objects. These objects act as a tactile contrast to impersonal displays in highly funded museum spaces. Despite the snaps' seemingly superficial content and stereotypical poses, the commonality of the images opens up a space of identification, dialogue, reflection and memory, or postmemory, work. This potentially enables the general public, who may not have been part of the community on display or not had any direct involvement with the events portrayed in the images, to empathise with the plight of that community (Blackman \& Harbord 2010; Cassidy 2009; Hirsch 2002, 2005; Kuhn 2002; Spence \& Holland 1991). The snaps also facilitate intergenerational links. They provide a common space of identification for audiences on a local, national and international scale (Figure 4). The snaps are exhibited in unlikely combinations and ironic contexts, often amongst other objects, such as machines in industrial heritage sites, or within calendar and postcard display stands at regenerated museum sites that commodify, repackage and often sentimentalise working-class culture.

Laminated interactive street maps of the districts are used to enable the community to conceptually repossess the area 
Figure 4: The Lowry, Salford - enlarged family snaps pasted to gallery wall, 2005
Figure 5: Interactive street map, Lower Broughton, Salford 7

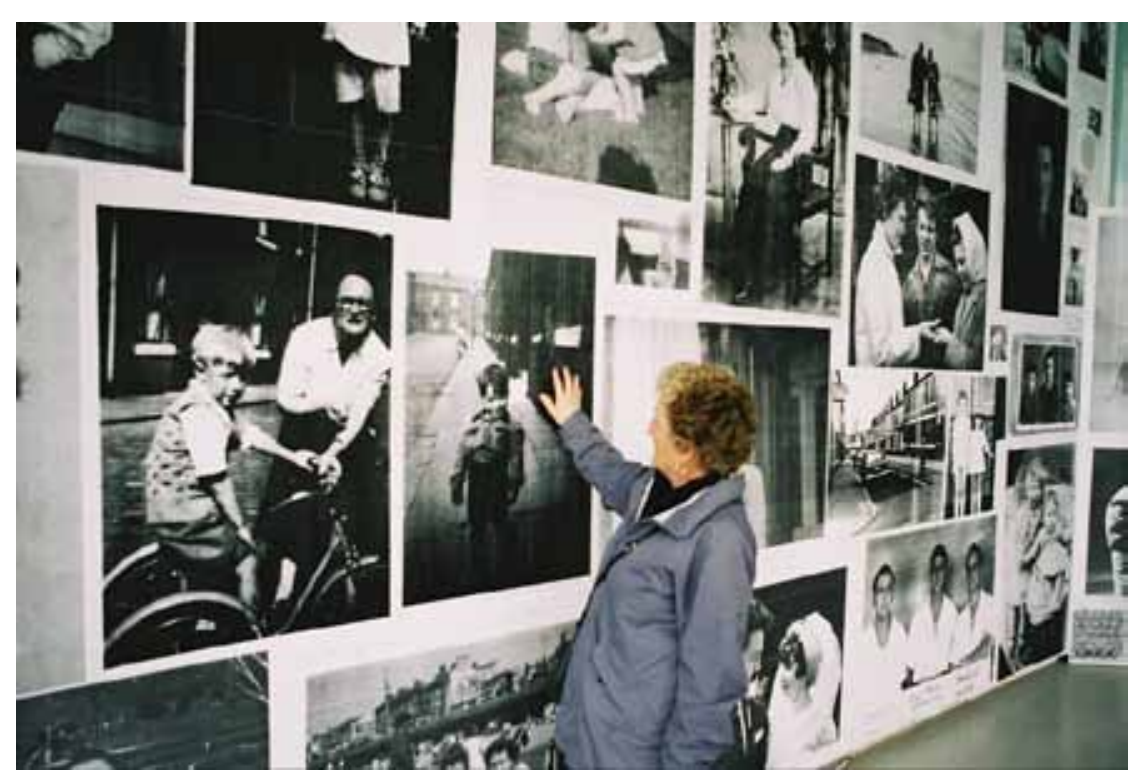

(Cassidy 2012b). When visitors gather around the maps, they are encouraged to place stickers on their former addresses, which are then catalogued and numbered. Current addresses are also catalogued. These records can be used to chart migration routes and contact residents for further interview (Figure 5). The names of places that are recalled, using the maps as inspiration, often substantially differ from titles on the official maps of the area. The installation spaces are often small, which encourages interaction and socialising, and visitors often remain there for substantial periods, recalling events, families, relations, traditions, buildings and places of work. The longer visitors remain, the more inclined they are to relax and reveal in-depth stories, and comment on sensitive subjects. Families often visit the installations in groups and intergenerational reflection is encouraged.

Oral histories are also collected in the space, enabling younger children to listen to their parents' and grandparents' stories as they interact with the images, objects and maps. The street signs are displayed alongside the maps, which anchor the maps and locate them in time and place. The street signs ground

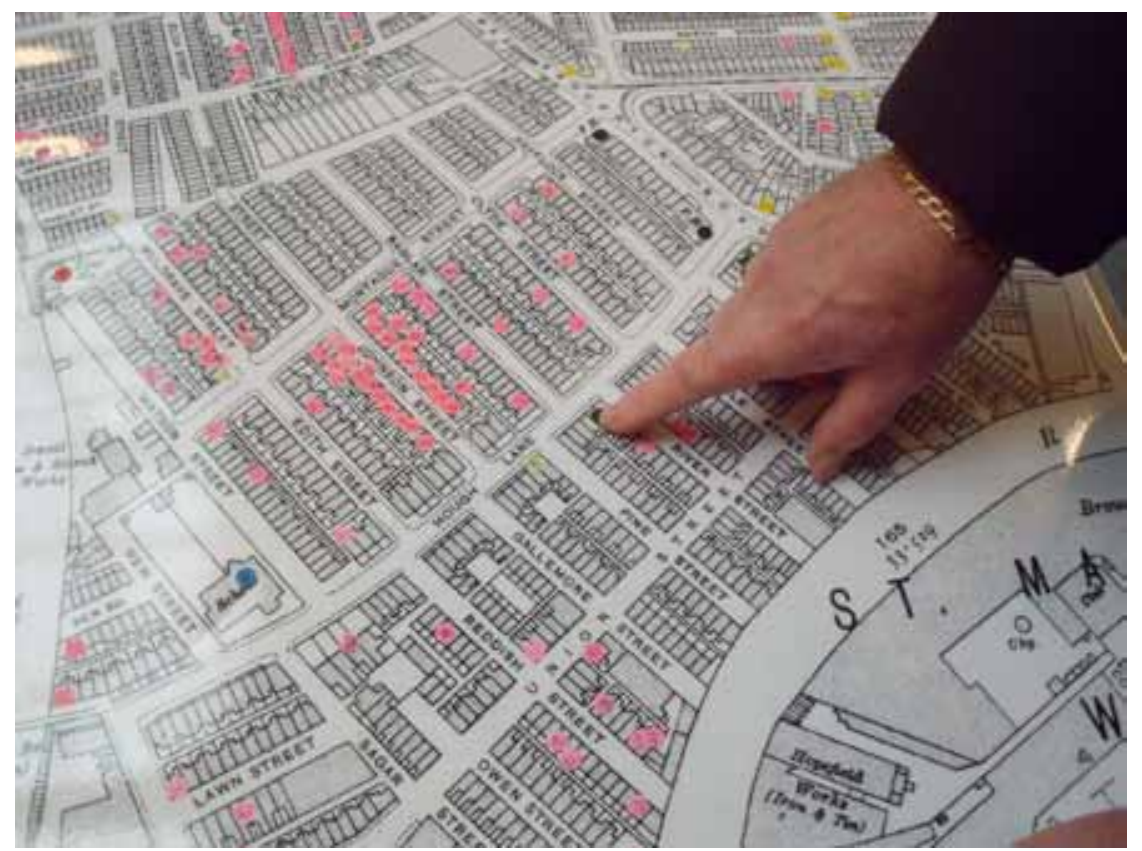


Figure 6: A-Z of Lost Salford Streets installation, People's History Museum, Manchester, 2011
Figure 7: Nora Street resident Elsie Winstanley (left), with the sign that she kept for 38 years. Friends Dorothy Criechton (centre) and Maureen Murphy (right) are also from central Salford districts

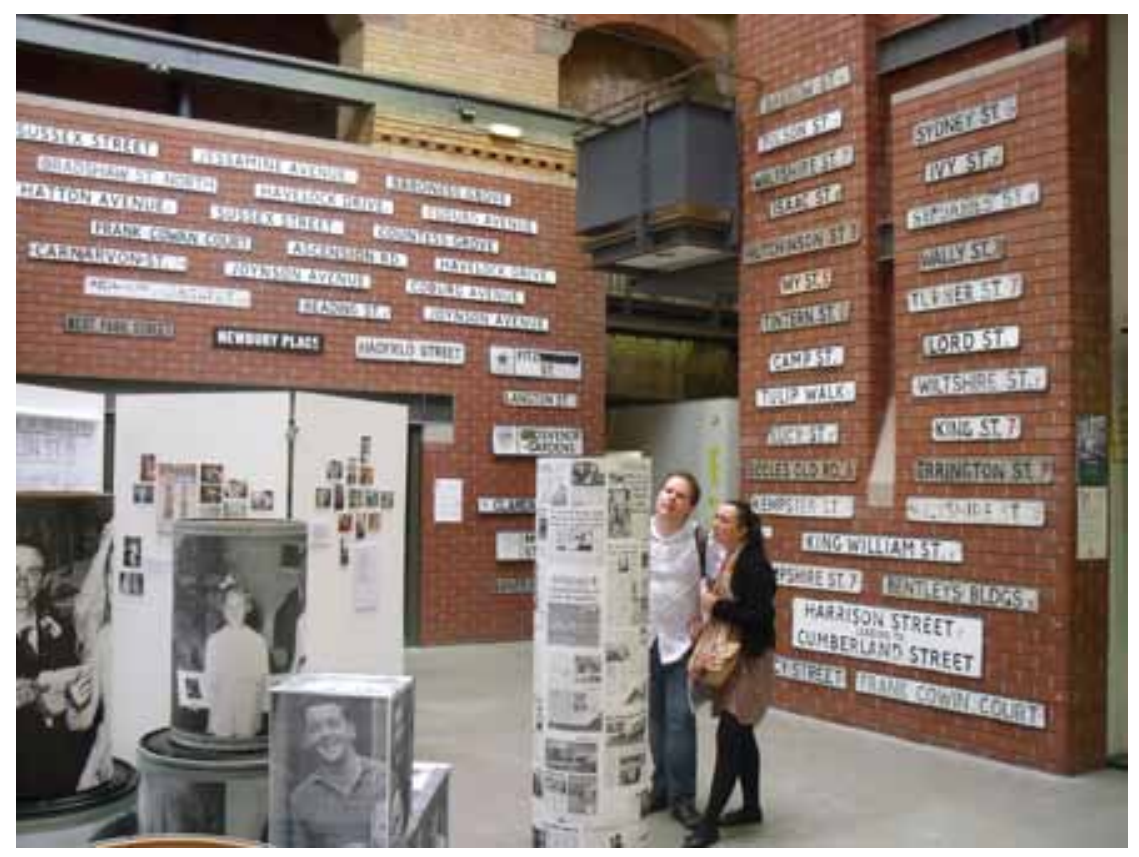

the installation as a place that is deeply meaningful to local visitors (Casey 2001). They also catalyse memories of related streets in that particular locality. These material remnants are rusting, partially decayed and contain the marks of past interaction (Figure 6). As such, they are intended to contrast with newly designed impersonal spaces (or non-places) of regeneration that hold no meaning for local communities, such as new apartment blocks (Woolrytch \& Sixthsmith 2005).

The installations are regularly advertised in the local press, who have cooperated in the process of publicity and collection, as has the BBC. Over 80 street signs from the area and other areas in the city have been collected, many belonging to residents who have had them since the 1960s or 1970s; others date from recent demolitions (Firgure 7). All the objects have intensely personal associations. As with the District Six street signs, they have become signifiers of extraordinary power, as layer after layer of meaning sediments around them (Bohlin 1998). The street names

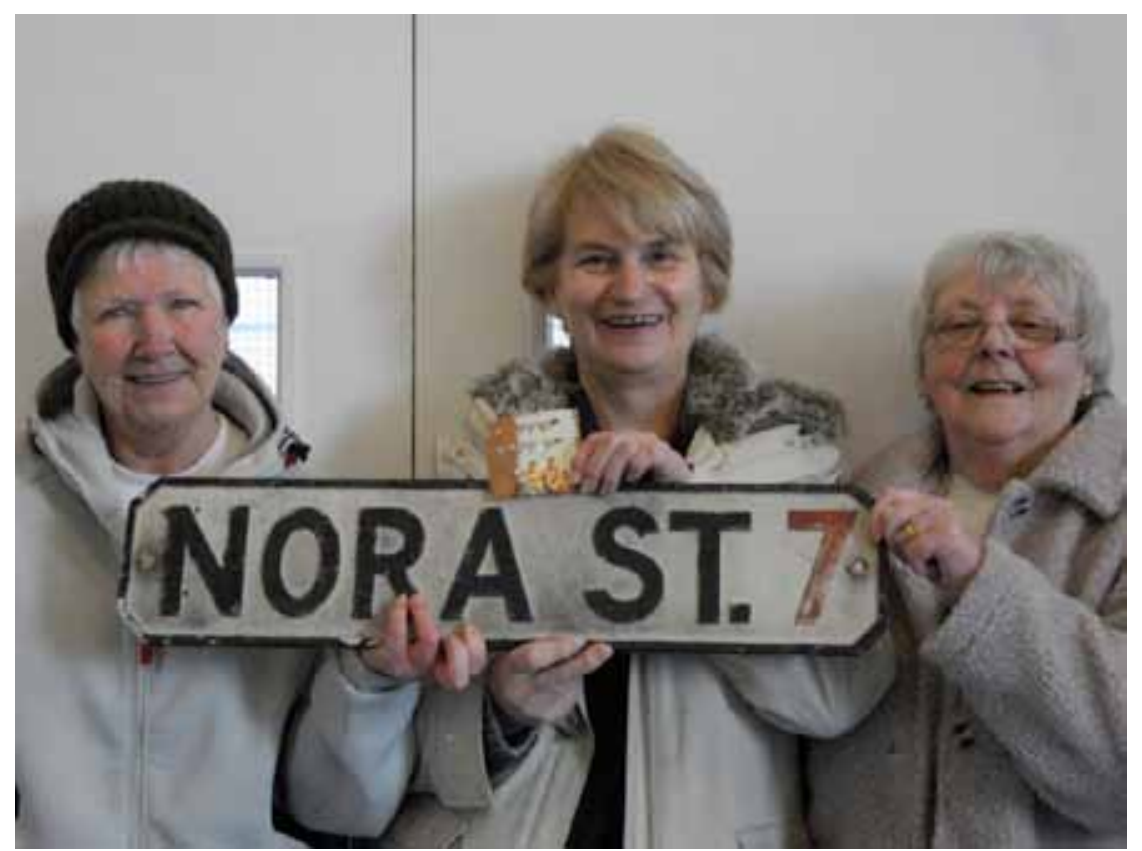


hold potentially countless personal and social memories and associations for generations of people. Autobiographical accounts that are related to the street signs can be collected and extended indefinitely by using the objects in the exhibitions. In this way, the objects are used as a sensory form of engagement.

Retracing Salford's outreach program also involves delivering educational workshops in schools and memory workshops with adults at local exhibition venues. Artists also work on the project in diverse media, to engage the community in both tangible and nontangible heritage projects, such as textiles work, live performance and drama, based on the remembered events of the area. It also entails working alongside other organisations in the city that have related interests, such as universities, The Working Class Movement Library, community centres and arts groups. This recently involved designing a program of events and presentations at The Working Class Movement Library, Salford, which was held over an extended period. This has sustained visitor participation at both the library and the Retracing Salford project, through the sharing of resources, contacts, archives and information. It has therefore become a mutually supportive process.

\section{REFLECTING ON METHODS OF ENGAGEMENT}

There has been a massive loss of sense of place in Salford over the past 40 years, as the vast majority of the architectural fabric has been erased in all urban districts. Coupled with this has been the lack of public commemoration of working-class culture, history and identity by the major institutions. In contrast to this absent public display, however, the Retracing Salford project, and its online development, has shown that many people place great value on urban community histories and heritage, by conserving and keeping objects in their homes, as private 'museums' to the streets they have lived in. Their in-depth knowledge of the urban clearance process and street life - and of industrial history, mining, war and urban culture - is profoundly engaging and informative. Hundreds of people have donated to our project and personal histories are recounted in the belief that this will lead to a more permanent institutional recognition of urban life. As historian Raphael Samuel has observed, the most interesting historical documents are often found in the home (Samuel 1996).

This process of interaction with everyday material culture, first observed at the District Six Museum, has acted as a form of social practice (Radley 1990), making possible a collective stamp of approval, which dissolves the formal distinction between organisers and visitors (Bohlin 1998). The memory workshops we have held in the exhibition spaces are where family photographs and related objects are collected, interviews are also conducted and general discussion is encouraged alongside large-scale street maps. This opens up individual and group reflection on the near past and on previously hidden memories. These memory workshops were inspired by the District Six Museum's use of family albums in their 
Two Rivers Project, which retraced communities in the peripheral districts that they had been relocated to. In Salford, it involves taking family albums into outlying districts (named overspill estates in the UK) and encouraging former residents of central urban districts to reflect on the removal process and their lives.

This participatory process has helped to build trust, as common ground is established between interviewers and the community. The method of reflecting on the loss of schools, clubs, teachers, shops, parks, streets, flats, factories, cultural traditions and so on bonds the community together and acts as a form of therapy. Judging by the reactions of ex-residents interviewed to date, many have a deep emotional attachment to place and community. Many remain in the exhibition space for long periods and become upset when recalling events associated with removal and demolition or their past life in the district.

Over the past three years, the archive of material culture has grown steadily. It has been supplemented by a glass plate negative collection, which we obtained from a studio photographer in the area, who recorded events and portraits over a 40-year period. This archive is similar to the Van Kalker archive, which is held at the District Six Museum. The online activities are constantly developing. Residents bring in family snaps of their former streets, which are then scanned in and uploaded to the website. This allows residents to become familiar with the use of digital technology and potentially archive their own images. Many residents have already formed online archives, as well as blogs and websites, and are engaged in social networking. We have found that combining both physical and digital exhibits contributes to social networking. As well, groups of ex-residents have begun to create their own online archive of family snaps on the Streets Museum's Facebook page, which has been set up alongside the website. All this activity shows the grass-roots interest in the project and the depth of feeling people have for the district and place they grew up in. At present the Streets Museum site is not interactive, in that it does not facilitate comments on each photograph and street. However, this is currently being developed. A main critical issue is how to police the site, to ensure comments are appropriate, as the images could potentially inspire a large amount of debate, and such monitoring would involve time and funding. Interestingly, the websites have attracted interest from ex-residents now in Australia, South Africa and the USA.

District Six has been subject to an intense level of interdisciplinary analysis, especially since the memory boom of the 1990s (Bohlin 1998; Coombes 2003; Field 2001; Hall 2006, 2007; Jeppie \& Soudien 1990, McEachern 2001; Rassool 2007; Rassool \& Prosalendis 2001). This research can potentially be utilised and extended in relation to other communities that have undergone similar processes, for example, other districts in Salford and Manchester, as well as Liverpool, Glasgow and London. Indeed, Coombes (2003) has drawn comparisons between the 
events in District Six and those in certain port areas in the UK, such as Toxteth in Liverpool 8, Tiger Bay in Cardiff and London's Docklands.

It truly amazed me to see the rapid development of the District Six Museum in a country with relatively few financial resources compared to those of European cities. Its success demonstrates that we do not necessarily need multi-million pound regeneration sites to attract visitors, but meaningful interactive displays that can engage, retain and sustain visitors over the long term. When the Retracing Salford project was exhibited at the local museum in 2008, it was found that the installations, plus weekly attendance by researchers to engage with residents, significantly increased visitor numbers to the museum by 23 per cent over a three-month period. This would undoubtedly have steadily increased, if the exhibition had remained as a permanent museum outreach project (Cassidy 2009). The Streets Museum website has since attracted over ten thousand visitors. Hundreds of families have personally donated snaps to it. The comments book displayed at our exhibition at the People's History Museum, Manchester, in 2011, was full of supportive statements, asking for a future permanent home for the collection. This has also occurred at every community venue we have exhibited in since (approximately six different locations). Publicity in Manchester newspapers has received a wide-ranging response, with residents constantly calling to request the inclusion of their histories in the project. On the whole. This process requires a number of staff members to initiate and maintain it, including an Archivist, an Educational Outreach Worker, an Oral Historian, a Curator, a Community Outreach Worker(s) and also Project Coordinators.

\section{CONCLUSION}

A major long-term objective of the Retracing Salford project is to continue to critically engage with dominant forms of historical representation, or absent commemoration in the city, using the District Six Museum methodologies briefly described in this article as inspiration. The goal is to work towards creating a more inclusive representation of urban community histories in the city, principally by involving more people as active participants in this process and debate.

This work in Salford, which is entirely independent of local museum collections policies, has demonstrated that visitors value low-budget, meaningful interactive exhibitions, which are produced by people who have a direct historical connection to the district as lived experience and who can engage residents in debate and reflection regarding the intricate details of the area and issues being faced today. Its further development will depend on support from a range of institutions, such as museums and universities, through the provision of space, staff, technology and facilities. In the current climate of wide-scale community clearance or eradication, as well as social alienation, this should be prioritised. 
Salford, and indeed all central Manchester districts are being confronted with social devastation, as all forms of the tangible past are removed. This process is part of an ongoing program of largescale community clearance and mass relocation. Supportive social networks are erased as part of this program. Projects that facilitate a sense of place, social networking, intergenerational education, skills building and links with the near past should therefore be encouraged. The clearances of the 1960s and 1970s were not blessed with projects of the kind discussed in this article; however, residents have patiently kept the material artefacts that now serve as evidence of those clearances - and this will be true of the current clearances, too. In the absence of the physical environment, this cultural material can now be used in diverse projects to educate and empower the community.

\section{ACKNOWLEDGEMENTS}

The author would like to thank the following people for their advice: Professor Jim Aulich, Dr Amanda Ravetz and Dr Nick Mansfield. Thanks, too, to Vice Chancellor Professor Martin Hall for his support at all stages of the project.

\section{REFERENCES}

Allen, C 2008, Housing market renewal and social class, Routledge, Abingdon, UK.

Bagnall, G 2003, 'Performance and performativity at heritage sites', Museum and Society, vol. 1, issue 3, pp. 100-07.

Bennett, T 1995, The birth of the museum, Routledge, Abingdon, UK.

Blackman, L \& Harbord, J 2010, 'Technologies of mediation and the affective: A case-study of the mediated environment of MediaCity UK', in D Hauptmann \& W Neidich (eds), Cognitive architecture: From biopolitics to noopolitics, architecture and mind in the age of communication and information, 010 Publishers, Rotterdam.

Bohlin, A 1998, 'The politics of locality: Remembering District Six in Cape Town', in N Lovell (ed.), Locality and belonging, Routledge, Abingdon, UK.

Casey, E 2001, Remembering, a phenomenological study, Indiana University Press, Bloomington, IN.

Cassidy, L 2009 'Salford 7: The representation and reconstruction of a lost working class community', unpublished PhD thesis, Manchester Metropolitan University, Manchester.

Cassidy, L 2012a, 'Salford 7/ District Six: Using material artefacts to facilitate memories of destroyed districts', in W Jackson, B Jeffery, M Marino \& T Sykes (eds), Crisis, rupture and anxiety: An interdisciplinary examination of contemporary and historical human challenges, Cambridge, UK.

Cassidy, L 2012b, 'Salford 7/District 6: The use of participatory mapping and material artefacts in cultural memory projects', in L Roberts (ed.), Mapping Cultures, Place, Practice, Performance, Palgrave Macmillan, Hampshire, UK.

Connerton, P 1989, How societies remember, Cambridge University Press, Cambridge, UK. 
Coombes, A 2003 History after apartheid, visual art and public memory in a democratic South Africa, Duke University Press, Durham, NC.

Dorling, D 2007, Poverty, wealth and place in Britain, 1968-2005, The Policy Press, Bristol, UK.

Engels, F 1958, The condition of the working class in England in 1844, Blackwell, Oxford, UK.

English Heritage 2008, Conservation principles: Policies and guidance for the sustainable management of the historic environment, English Heritage, London.

Field, S 2001, Remembering forced removals in Cape Town, Centre for Popular Memory, University of Cape Town, Cape Town.

Hall, M 2006, 'Identity, memory and countermemory: The archaeology of an urban landscape', Journal of Material Culture, vol. 11, nos 1-2, pp. 189-209.

Hirsch, M (ed.) 1999, The familial gaze, Dartmouth College, Hanover, NH.

Hirsch, M 1997, Family frames: Photography, narrative and post memory, Harvard University Press, Cambridge, UK. Lawrence dates okay? you had 2001 and 2005 but I can only find these original publications.

Jeppie, S \& Soudien, C 1990, The struggle for District Six, Blackshaws, Cape Town.

Kavanagh, G 1999, Making histories in museums, Leicester University Press, London.

Kidd, A \& Roberts, K 1985, City, class and culture: Studies of cultural production and social policy in Victorian Manchester, Manchester University Press, Manchester, UK.

Kuhn, A 2002, Family secrets: Acts of memory and imagination, Verso, London.

Macdonald, S (ed.) 1998, The politics of display: Museums, science, culture, Routledge, London \& New York.

Mallinson, S 2003, 'Historical data for health inequalities, conceptualising and measuring the health impact of place: Focus on Salford', Journal of The British Sociological Association, vol. 37, no. 4, pp. 771-80.

McEachern, C 2001, 'Mapping the memories: politics, place and identity in The District Six Museum, Cape Town', in A Zegaye (ed.), Social identities in the new South Africa, after apartheid, vol. 1, Kwele Books, Cape Town, pp. 223-47.

Norris Nicholson, H 2000, 'Two tales of a city: Salford in regional film making c.1957-1973', Manchester Regional History Review, vol. 15, pp. 41-53.

Peck, J \& Ward, K 2002, City of revolution: Restructuring Manchester, Manchester University Press, Manchester.

Radley, A 1990, 'Artefacts, memory and a sense of the past', in D Middleton \& D Edwards (eds), Collective remembering, Sage, London.

Rassool, C 2007, 'Memory and the politics of history in The District Six Museum', in N Murray, N Shepherd \& M Hall (eds), Desire lines: Space, memory and identity in the post-apartheid city, Routledge, Abingdon, UK.

Rassool, C \& Prosalendis, S (eds) 2001, Recalling community in Cape Town, District Six Museum Foundation, Cape Town. 
Roberts, R 1971, The classic slum: Salford life in the first quarter of the century, Penguin, London.

Salford City Council, 2007, Broughton Ward profile, Salford City Council, viewed 15 December 2011, www.salford.gov.uk/council/ salfordwardprofiles.htm

Samuel, R 1996, Theatres of memory, Verso, London.

Schofield, J 2009, Aftermath: Readings in the archaeology of recent conflict, Springer, USA.

Shapely, P 2008, 'Social housing and tenant participation', History and Policy, March, viewed 30 July 2012, www.historyandpolicy.org/papers/ policy-paper-71.html.

Somerville, P 2011, Understanding community: Politics, policy and practice, The Policy Press, Bristol, UK.

Soudien, C 2008, 'Memory and critical education: Approaches in The District Six Museum', in B Bennett, C Julius \& C Soudien (eds), City, site, museum: Reviewing memory practices at The District Six Museum, The District Six Museum, Cape Town.

Spence, J \& Holland, P 1991, Family snaps: The meanings of domestic photography, Virago, London.

Western, J 1996, Outcast Cape Town, University of California Press, Berkeley, CA.

Wilkinson, A 2006, Pathfinder, SAVE Britain's Heritage, London.

Woolrych, R, \& Sixsmith, J (In press), 'Placing well-being and participation within processes of urban regeneration', International Journal of Public Sector Management. 